\title{
Science Teachers' Instructional Practices in Malaysian and German Secondary Schools
}

\author{
Ai Jing Tay ${ }^{1} \&$ Salmiza Saleh ${ }^{1}$ \\ ${ }^{1}$ School of Educational Studies, Universiti Sains Malaysia, Pulau Pinang, Malaysia \\ Correspondence: Ai Jing Tay, School of Educational Studies, Universiti Sains Malaysia, Pulau Pinang, Malaysia. \\ E-mail: aijing1@hotmail.com
}

Received: May 25, 2019

Accepted: June 19, 2019 Online Published: July 12, 2019

doi:10.5539/jel.v8n4p124

URL: https://doi.org/10.5539/jel.v8n4p124

\begin{abstract}
Advancement of science and technology in many areas has made progress on human lives more developed than the ancient time. A strong science education would be able to equip our younger generation with the skills needed to ensure them for securing a better job in future. Thus, this study is to compare the science teachers' instructional practices in Malaysian and German secondary schools. A total of sixteen science teachers were involved where eight of them were from the German secondary schools and another eight of them were from Malaysian secondary schools. This study was done by conducting classroom observations and semi-structure interviews. The data collected were then analyzed qualitatively based on Dancy and Hendersons' framework of instructional practices. In conclusion, Malaysian and German science teachers have similar source of knowledge, definition of students' success, learning modes, type of motivation and problem-solving skills where they show differences in the interactivity of the classroom, instructional decisions, assessment, content and instructional design. There are also ten good instructional practices found in this study which can be adapted in both nations to improve their science education.
\end{abstract}

Keywords: instructional practices, science education, secondary school, Malaysia, Germany

\section{Introduction}

It is undeniable that our world is getting advanced gradually. Technologies had created new challenges for educational institutions (Papadakis, 2016; Drossel et al., 2017) and acted as catalysts which can refurbish the way toward educating and learning (Ismail et al., 2016; Papadakis et al., 2016). Mobile devices have various distinctive features which might affects certain pedagogies (Papadakis, 2018). Hence, looking at the current rate of technological and scientific advancement that our world is heading to, there is an obvious need for us to look into the preparation of our younger generation for the future with a steady knowledge and understanding of the science.

According to the Programme for International Student Assessment (PISA) in 2012, it is found that Malaysia score was far underneath the average worldwide score where Germany ranked 16 out of 52 (OECD, 2012a). OECD found that German students have higher ability to solve a range of pure and applied problems than Malaysian students (OECD, 2012b). German students' exceptional execution in science literacy could be additionally clarified by their lesser feelings of stress when dealing with science whereas the larger amounts of uneasiness and worries in learning among the Malaysian students could be the reason that Malaysian students failed to meet the expectations results (OECD, 2012b).

Furthermore, German teachers adapt their lesson to the students' needs more frequently than Malaysian teachers (OECD, 2016). German teachers monitor individual student progress consistently throughout the academic year (Mullis et al., 2012a). However, the teaching strategy in Malaysia is deeply relied on examinations-based (Mullis et al., 2012b). Malaysian teachers tend to give more monitoring and support towards students with better results while de-prioritizing the weaker students (Zamir \& Faizli, 2013).

As per literature, German science teachers are ahead of Malaysian science teachers where Malaysian science teachers still using the traditional instructional practices in their lessons. Thus, the aim of this study is to determine the similarities and differences of science teachers' instructional practices in Malaysian and German secondary schools as well as determine the good instructional practices found in both nations. 


\section{Literature Review}

\subsection{Instructional Practices}

Instructional practices are firmly connected to the teachers' action in a classroom. It is specific instructing strategies that guide cooperation in the classroom. Grasha (1996) defined it as the individual characteristics and behaviours on how instructors lead their classes. Instructional practices are the behaviours of a teacher which the teacher found comfortable and consistently practised them over time in the classroom (Elliott, 1996; Ahmed, 2013). Instructional practices are related to effective classroom learning (OECD, 2009).

According to Dancy and Henderson (2007), there are two types of instructional practices which are the traditional instructional practices and alternative instructional practices. Basically, the traditional instructional practices have a minimal interactivity while the alternative instructional practices have significant interactivity. Typical characteristics of traditional instructional practices are teacher who talks more and poses questions rather than student who talk. It additionally relies much on textbooks (Emaliana, 2017). They are information providers or evaluators to monitor students to get the right answers, yet students passively receive information (Emaliana, 2017). On the contrary, alternative instructional practices do not only rely on textbooks to present content to a class of learners. The teachers in this approach discover routes for students to relate science to the world outside of the classroom (Tobin \& Garnett, 1988). Thus, the alternative instructional practices centred around students' thoughts.

\subsection{Science Teachers' Instructional Practices in Malaysia and Germany}

Formerly, traditional instructional practice was utilized in the Malaysian school. It incorporates repetitive learning styles and examination-oriented system in Malaysian formative school years (Tengku Kasim, 2014). It led to the adoption of certain teaching and learning techniques such as rote learning and spoon feeding (Tengku Kasim, 2014). According to Tengku Zainal, Mustapha and Habib (2009), some Malaysian teachers prefer to proceed with the traditional practices as opposed to being creative or inventive. They lean towards a traditional classroom approach rather than alternative teaching practices which require more effort, time and creative thinking during their lesson.

Saleh and Aziz (2012) additionally showed that the instructional practice in Malaysia has a negligible level of interaction, whereby the Malaysian teachers did most of the talking and instructing while only several students contributed their views. Besides, Malaysian science teachers were showing materials from a textbook. They conducted demonstrations and laboratory activities occasionally to verify the concepts taught in classroom and to explain some exercises given at the end of the textbook, in order to familiarise students with examination questions (Saleh \& Yakob, 2014b; Saleh \& Aziz, 2012; OECD, 2009). It is supported by Sim and Arshad (2013)'s investigation where it is found that most of the Malaysian science teachers conducted traditional instructional practices such as giving clarification in theory lessons. According to Saleh and Liew (2018), Malaysian teachers were trying to practice student-centered teaching approach, but they still dominated their classrooms.

On the contrary, German science teachers are far ahead compare to Malaysian science teachers. In 1990, a study reported German science teachers used more instructions of task-specific strategies in their lessons (Kurtz et al., 1990). It is supported by Björkmana and Tiemanna (2013) findings where German lessons are organised in a more product-oriented way and class discussion represents a very dominant teaching method. German classrooms were also afforded more generous chances to formulate prove based clarifications (Forbes et al., 2014).

Besides, Tytler, Chen and Freitag-Amtmann (2017) discovered that German lessons were conducted through dialogue. A series of activities designed to encourage dialogue and probing of student ideas, with teachers subtly introducing and reintroducing ideas to shape understandings. Students explore, record and share findings with minimal support rather than strongly guided instruction. German students participated actively in the class discussion without making much noise (Saleh \& Liew, 2018). Moreover, the German lessons move from individual understanding to a shared scientific understanding of the key characteristics of a problem (Tytler et al., 2017). German teachers believe that it is their duty to convey the weaker students along and to assist them (Stevenson \& Nerison-Low, 2002). They encouraged peer tutoring by having students work in pairs or in small groups (Stevenson \& Nerison-Low, 2002). Furthermore, most German teachers adopt a diverse style of teaching that incorporates several strategies in each lesson, for example, lectures, interactive questioning between teacher and students, group work, and demonstrations. Thus, there are no single mode of teaching to characterizes German instructional practices. 


\subsection{Effective Teaching}

Teaching is not just the effective transference of knowledge. Students need to start learning and keep up with their engagement in learning to develop themselves into independent lifelong learners. According to the researchers, the best teachers have profound knowledge on the subjects they teach as well as understand the ways their students learn by taking the content into consideration. The teacher should be able to have the capacity to assess the reasoning behind students' own particular techniques and identify students' common misconceptions (Coe et al., 2014). Besides, a good teacher has a good quality of instructions such as effective questioning and the assessment used by the teacher. The teacher must also have the capacity of asking diverse questions to achieve different objectives of the lessons (Ko \& Sammons, 2013). Specific practices like reviewing prior knowledge, providing model responses for students, giving sufficient time for practising to implant abilities and continuously presenting new learning are the elements of high-quality instruction (Coe et al., 2014).

Msimanga (2014) contended that students should be given a chance to reflect on what they have learnt to see whether effective learning occurred. Furthermore, Msimanga (2014) argued that effective learning requires more on making various connections of new ideas to old ones and sometimes requires the individual to fundamentally rebuild thinking. Effective learning happens when students are given a chance to reflect on their learning. It requires students to restructure their thinking by depending on acquired new knowledge (Msimanga, 2017).

\subsection{Framework for Articulating Instructional Practices}

The aim of this study is to compare the instructional practices found in Malaysian and German science teachers. Thus, Dancy and Henderson's (2007) comprehensive framework was used in this study. Interactivity, instructional decision, knowledge source, student's success, learning mode, motivation, assessment, content, instructional design and problem solving are the ten categories found in the framework which acts as a tool to compare the instructional practices of an individual. The practices based on the ten categories fall into traditional instructional practices and alternative instructional practices as explained in Table 1.

Table 1. Main categories of practices

\begin{tabular}{lll}
\hline & Practices consistent with traditional instruction & Practices consistent with alternative instruction \\
\hline Interactivity & One-sided discourse, passive students & Conversations, active students \\
Instructional decisions & Decision made by teacher & Decision shared by teacher and students \\
Knowledge source & Students receive expert knowledge & Students develop own knowledge \\
Student success & Success against pre-set standards & Success measured by individual improvement \\
Learning mode & Competitive or individualistic learning mode & Cooperative learning modes \\
Motivation & External motivators & Internal motivators \\
Assessment & Knowledge-based assessment & Process based assessment \\
Content & Explicitly teach only science facts and principles & $\begin{array}{l}\text { Explicitly teach learning, thinking and problem-solving } \\
\text { skills in addition to science content }\end{array}$ \\
Instructional design & Knowledge driven based on understanding of the & $\begin{array}{l}\text { Student driven based on understanding of student } \\
\text { learning within the discipline of science }\end{array}$ \\
Problem solving & structure of science & Creative problem solving: Problems assigned to students \\
& Formulae problem solving: Problems assigned to & are novel to solve and may have unknown or open-ended \\
\end{tabular}

Source: Adapted from Dancy \& Henderson, 2007.

\section{Methodology}

\subsection{Research Design}

In this study, an attempt is made to compare the science teachers' instructional practices found in Malaysian and German secondary school and also to suggest good instructional practices based on the comparison found in this study. In order to extract data that satisfyingly addressed research questions, a comparative case study method was used in this study. This research methodology allowed the researcher to understand and compare the instructional practices of two nations. Case study methods are given to the requirement for a straightforward and fair process of data analysis with accurate presentation of carefully selected information (Hakim, 2000). Procedures connected to case study methods have been portrayed by Merriam (1998) as including conducting literature review, constructing a theoretical framework, identifying a research problem, crafting and sharpening research questions and selecting the sample. In this manner, the researcher used Dancy and Henderson's (2007) comprehensive framework to categorise the science teachers' instructional practices found in Malaysian and 
German secondary schools.

This study involved collection of qualitative data from classroom observations and semi-structured interviews. In this study, observation is done to understand the situation being described, see things that might otherwise be unconsciously missed in the first stage and discover things that respondents might not uninhibitedly discuss in the interview situations (Cohen, Manion, \& Morrison, 2007; Kawulich, 2012). The researcher chose non-participants and an overt and unstructured observation in this study. The researcher participated in the lesson by sitting behind of the classroom and observed the lesson conducted. The participants had acknowledged the presence of the researcher in the classroom before the researcher observed the lesson. Thus, the researcher observed the classroom observation of the same participant at least twice to avoid the participants changed the classroom activities due to the aim of this study. A total dataset of 32 lessons were observed, annotated and recorded as field notes.

Furthermore, semi-structured interview was conducted with high school science teachers to investigate qualitatively and research further into issues that were impractical to obtain from the classroom observations (Fraenkel, Wallen, \& Hyun, 2012). The researcher analysed the similarities and differences found in between Malaysian and German science teachers based on the ten categories stated in the Dancy and Henderson's comprehensive framework (2007).

\subsection{Sampling}

The main data collection in this study involved the classroom observations and holding semi-structured individual interviews with eight teachers who were currently teaching science subjects in Year 8 to Year 10 in German secondary school and eight Malaysian science teachers who are teaching Form 4 science classes. The teachers were those who teach biology, chemistry, physics and general science. Teacher A, Teacher B, Teacher C, Teacher D, Teacher E, Teacher F, Teacher $\mathrm{G}$ and Teacher $\mathrm{H}$ were from Malaysian secondary schools whereas German science teachers were Teacher K, Teacher L, Teacher M, Teacher N, Teacher O, Teacher P, Teacher Q and Teacher R.

A purposive sampling technique was used in this study due to the small sample size involved. The states and the schools in both countries were purposely selected. The secondary schools from the state of Selangor and Wilayah Persekutuan Kuala Lumpur were selected to carry out the research in Malaysia. In Germany, the secondary schools in Bavaria and Saxony were selected. It was then followed by the purposive sampling technique to draw the science teachers from the selected schools. Parahoo (1997) depicts purposive sampling as a method of sampling where the researcher chooses who to be participated in the study in light of their capacity to give essential information. It is one of the most financially savvy and time-effective sampling methods. Due to the time and money constraints, the researcher purposely visited the selected secondary schools in Malaysia and Germany to observe the teaching and learning process. Besides, the participants involved in this study are teachers who teaching science in the secondary schools and those who are willing to open their classrooms for the classroom observation.

\subsection{Data Collection Procedures}

On each day of observation, the researcher attended the lesson to collect data. The researcher used a technique known as observer as participant in this study. The researcher acted as a neutral role in this study by observing the lessons conducted by the teachers without participating in the activities and jotting down the observation. The sixteen science teachers had acknowledged the presence of the researcher before the researcher entered the classroom. As the lesson progresses, the following criteria were recorded: field notes about the duration of each lesson, students' seating configuration, instructional aids used by teachers, medium of instruction, classroom environment and activities carried out in the classroom. The information recorded were mainly about the teachers' instructional practices as well as the interaction between the teacher and the students.

Moreover, a semi-structured interview was conducted with the sixteen science teachers who had participated in the classroom observation to investigate the study qualitatively and look further into the issues which were impractical to obtain from classroom observation (Fraenkel, Wallen, \& Hyun, 2012). This method provided the opportunity for the researcher to re-interview the same participants who had also involved in the classroom observation. The questions asked in the semi-structured interview were questions related to the research questions where the element of instructional practices that cannot be observed from the classroom observation such as assessment and the definition of students' success. Firstly, the researcher started each interview with an exchange of greetings and a note of thanks on the interviewee's acceptance to participate in this study. The researcher then reviewed the purpose of this study and how the information was going to be used after self-introducing. The participants were guaranteed that their responses would be treated confidentially and would 
be used for research purposes only. The researcher also reminded the participants that the interviews were being audio recorded by using mobile phone and they could ask for the recording to be stopped if they were not comfortable with it. The researcher gave a verbal informed consent and obtained the response of agreement from the participants before starting the interview.

At the end of the interview session, the researcher discussed the ways to make further contact with the participants. The researcher then sent the transcript to the participants. The participants were encouraged to read, comment and make additional changes to the transcript. They were asked to review whether their words matched with what they had intended. The examined transcripts were then used for data analysis. The data obtained from both classroom observations and interviews were then analysed qualitatively.

\subsection{Data Analysis}

Braun and Clarke (2006)'s thematic analysis structure approaches were used to analyse the data within and across each data source. Firstly, the analysis started with the familiarisation process where the data from the field notes and the audio recordings were transcribed into a word document. The field notes and the audio recordings were expanded into a rich description using computer to produce a detailed report on the classroom teaching and learning process. The transcribed text and field notes were read carefully to obtain a general and comprehensive impression of the content and context. It was then reread to look for highlights in the text which were of interest with respects to the research questions. Each field note and interview transcript were coded line-by-line.

Once the data set had been read, re-read, coded and re-coded, all the codes created were collated into possible themes. The researcher tried to refocus the analytical process in a broader level of analysis. The researcher identified emerging themes that could group codes together. The related codes were listed into respective categories according to Dancy and Henderson's framework. Then, the coded text extracted from the sixteen science teachers on interactivity was read through by two expert science teachers to determine intercoder agreement. According to Cohen Kappa, it is found that the two science teachers had agreed with the coding. The themes were revisited and re-read a few times to ensure the experience told was clear and dependable. The findings were then reported.

\section{Results and Discussion}

Based on Dancy and Henderson's comprehensive framework, there are similarities and differences found in Malaysian and German science teachers' instructional practices. The findings were compared and discussed.

\subsection{Similarities of Science Teachers' Instructional Practices in Malaysia and Germany}

Based on the findings, it is found that the similarities of instructional practices between Malaysian and German secondary schools could be seen in terms of several categories namely knowledge source, definition of students' success, learning modes, motivation and problem-solving skills.

\subsubsection{Knowledge Source}

Malaysian and German science teachers used traditional instructional practices in delivering the science knowledge to the students. They transferred science concepts to their students where their students received the science knowledge passively. All the Malaysian science teachers distributed notes to their students before the lesson started. As per Tengku Kassim (2014), the Malaysian education system has led to spoon-feeding where the teachers tend to give clarification in the classroom (Sim \& Ashrad, 2013) and transmit all the science knowledge in the theory lesson. Most of them German science teachers asked their students to copy down the notes written on the whiteboard except Teacher L. Besides, all the Malaysian and German science teachers demonstrated the experiments in the classroom occasionally without allowing their students to fully participate in the process. They still perceived their main role as the purveyor of information and instruction who decide most of the teaching and learning activities. Thus, the findings oppose with Tytler, Chen and Freitag-Amtmann (2017) where they stated that German students explore, record and share findings with minimal guided instruction.

\subsubsection{Definition of Students' Success}

Malaysian and German science teachers have the same perspective when defining students' success. The finding was consistent with Saleh and Yakob (2014) findings where Malaysian science teachers measured the success of the students by individual improvement. All the Malaysian and German science teachers defined their students' success based on their individual improvements. As stated in The Star (2017), success is subjective, and it differs from one individual to another. Teacher A, Teacher C, Teacher G, Teacher $\mathrm{H}$ and Teacher $\mathrm{O}$ said that attitudes are the most important criteria that determine the student's success whereas Teacher B, Teacher D, Teacher E 
and Teacher F said that the students have to try their best when learning science. Teacher K and Teacher Q from Germany stated that a successful student is a student who has learned to improvise and adapt the knowledge in his future whereas Teacher $\mathrm{L}$ and Teacher $\mathrm{N}$ said that a student with a high level of motivation towards the subject is a successful student. Besides, Teacher M, Teacher P and Teacher R stated that examination results are not important as long as their students enjoy learning in the classroom. In short, all of them stated that the examination results did not determine their students' success in the classroom.

\subsubsection{Learning Modes}

Despite the fact that German science teachers used small groups and peer tutoring as integral parts of classroom instruction (Stevenson \& Nerison-Low, 2002), the students are as yet evaluated individually just like Malaysia. Almost all of them only assigned individual assignments in the classroom which do not allow their student to work in pairs or groups. Although Teacher $\mathrm{E}$, Teacher $\mathrm{F}$ and Teacher $\mathrm{H}$ assigned group works, their students still had to hand in the report individually at the end of the lessons. Teacher L, Teacher N and Teacher Q also marked their students' script individually in spite of the fact that their students could discuss among themselves when solving the problems.

\subsubsection{Motivation}

Malaysian and German science teachers are internal motivators where they always asked feedbacks and comments from their students. It supported the past research where teachers from both nations practiced effective feedback in their classrooms (Saleh \& Liew, 2018). Moreover, they also linked their lesson with the daily life situations. Teacher A used analogy where she described the liver as a part just like the checkpoint in cross-country where Teacher $\mathrm{C}$ explained the public water system when she teaches the water pressure. Teacher E started the lesson with the simple English word "exit" before introducing exothermic to her students. Besides, Teacher B, Teacher D and Teacher F always motivate their students by praising them. Teacher $\mathrm{G}$ and Teacher $\mathrm{H}$ corrected their students patiently when their students make mistakes during the lessons. It goes the same with the German science teachers. They always praise their students. Teacher N showed his students the tutorial video about the explosion in the lesson. It also can be observed in Teacher L, Teacher M and Teacher P lessons where they corrected their student mistakes. Humans always learn from their mistakes and learning happens when students have the opportunities to reflect on their learning (Msimanga, 2017).

\subsubsection{Problem Solving}

Malaysian and German science teachers also have a similar view in problem solving. The instructional practices conducted by Malaysian and German science teachers remained in between traditional and alternative instructional practices in solving the problems. It was observed that Malaysian and German science teachers anticipated their students would be able to clarify and foresee the questions posed to them. The solutions of the posed problems are expected to include a correct numerical answer in the physics' lessons conducted by Teacher $\mathrm{C}$ and Teacher $\mathrm{F}$ from Malaysia and Teacher M, Teacher N, Teacher P and Teacher R from Germany. Notwithstanding, the problems posture in German schools incorporate some ill-defined concepts which have excess information for the students to think before answering the questions as Teacher $M$ stated that there are lengthy questions which include unnecessary information. In contrast, all the problems posed in Malaysian schools are well-defined concepts from the textbooks or workbooks (Saleh \& Aziz, 2012; Saleh \& Yakob, 2014).

\subsection{Differences of Science Teachers' Instructional Practices in Malaysia and Germany}

The findings found that the differences in instructional practices between Malaysian and German secondary schools are obvious in terms of its interactivity, instructional decisions, assessment, content and instructional design.

\subsubsection{Interactivity}

Malaysian science teachers have huge different in the classroom interactivity as compared to German science teachers. Malaysian science teachers have minimal interaction with their students where they always gave lectures in front of the classroom without involving the students expect Teacher F. It supported previous findings where the Malaysian science teachers were more inclined to practice a one-way communication (Saleh \& Aziz, 2012; Saleh \& Yakob, 2014) and the activities conducted in the classroom was the most on whole class lectures (Saleh \& Yakob, 2014). The Malaysian students were passive where they rather prefer answer in group than raise their hands to state their ideas (Saleh \& Liew, 2018). It is in contrast with German science teachers where the German science teachers supported inquiry and lesson conducted through dialogue (Tytler, Chen, \& Freitag-Amtmann, 2017). German students actively discuss about the topic of the lesson with their teachers. Although Teacher $\mathrm{C}$, Teacher $\mathrm{O}$ and Teacher $\mathrm{R}$ used whole class teaching methods in their lessons, they 
frequently made open inquiries and enable the students to share their thoughts during the lessons. Class discussion is a very ruling teaching method in German lessons (Björkman \& Tiemanna, 2013) and it is conducted by moving from individual understanding to a shared scientific understanding of the problem (Tytler, Chen, \& Freitag-Amtmann, 2017).

\subsubsection{Instructional Decision}

Based on the findings, the instructional decision made by both nations are different as well. Most of the Malaysian science teachers taught the science content in the classroom within a well-planned time. They dominated the lessons by determining the activities and the contents of the lessons except for Teacher $\mathrm{F}$ who asked his students to present their group project in the classroom whereas the other students commented on it. The discourse in the Malaysian classroom still seems to be focused on the teacher's ideas whereas students are only supposed to follow orders (Saleh \& Yakob, 2014; Saleh \& Aziz, 2012). On the contrary, German science teachers shared the instructional decision with their students. The German students have the chance to share their experiences with their classmates and their science teachers additionally give them a chance to present new knowledge as well as explain the topic to their classmates. It can be observed in Teacher K's lesson where he asked his students to state the example before he discussed it. Besides, Teacher $\mathrm{M}$ and Teacher $\mathrm{N}$ asked the students to conduct the experiments either at home or in the laboratory and explained the results of the experiments to their classmates. As per Koballa et al. (2000), students should learn actively and more motivate to learn when the students are given chances to make contributions during the lessons. Cooperative learning are essential elements of a learning process full of opportunity and motivation (da Luz, 2015).

\subsubsection{Assessment}

The findings also showed that both nations have different assessments. Teacher $\mathrm{H}$ stated that Malaysian students need to develop higher order thinking skills as stated in the Malaysian Education Blueprint (Ministry of Education, 2015). Teacher E said that their school sets a rule where the questions asked in the examinations must consist $40 \%$ of application questions whereas the other Malaysian science teachers stated that the questions they asked in the examinations are new and challenging questions where some of it were created by themselves and some of it adapted from the past year questions. Thus, the problem-solving questions asked in Malaysian examinations changed from repetitive questions to more challenging questions which the students have to apply their knowledge when answering the questions. However, the problems posed in German examinations were repetitive questions. Most of the German questions were tested on factual recall and only $20 \%$ of the questions were based on the students' understanding. All of them stated that the repetitious questions were the examples taught in the classroom. Hence, it is found that Malaysian science teachers are ahead of German science teachers where Malaysian science teachers used process-based assessment where German science teachers still stuck in the traditional methods.

\subsubsection{Content}

The analysis of the classroom observation showed that the Malaysian science teachers have been moving toward the alternative instructional practices. This disagreed with Tengku Kasim (2014) where students were resorted to memorise facts to excel in their examinations and tests. Most of the Malaysian science teachers used broad content in their classroom. They taught learning and thinking in classroom except Teacher $\mathrm{H}$ who focused on science facts and principles. Most of the Malaysian science teachers focused on conceptual understanding where they frequently used examples which can be found in the daily life to relate science knowledge to their students' prior knowledge. Although Germany is a developed country, most of the German teachers are still using knowledge-based content. Most of the them transferred the knowledge directly to students and they are more focused on formulae and derivations except for Teacher $\mathrm{L}$ who asked his students to search the information on the internet and do a mind map about it. This finding supported Forbes et al. (2014) findings where German classrooms were afforded more generous chances to formulate prove based clarifications.

\subsubsection{Instructional Design}

Malaysian science teachers used knowledge-driven instructional design whilst the instructional design in the German science classroom showed favour towards students-driven instructional design. Most of the Malaysian teachers' instructional designs were based on an understanding of the structure of science. All Malaysian science teachers prepared lesson plan on what, when and how the lesson is going to be conducted. Teachers tend to use their autonomy to decide the topic without giving autonomy for students to voice out (Saleh \& Aziz, 2012). On the contrary, German science teachers changed their lessons according to their students. It was proven in Teacher $\mathrm{M}$ and Teacher $\mathrm{N}$ classroom where they changed activities in the lesson when the students did not prepare it. 
They were much more flexible compared to Malaysian science teachers where Malaysian science teachers have a well-prepared lesson plan before entering the classroom.

\subsection{Good Instructional Practices in Teaching Science}

In light of the outcomes acquired from the classroom observations and semi-structured interviews, there are a few instructional practices which are found to be beneficial in teaching science and can be adapted by both nations.

\subsubsection{Interactivity}

Firstly, science teachers can start the lesson by showing some interesting activities or associating the lesson to students' daily life to attract the student's attention and interest before teaching the science concepts. Teacher F asked her students to feel the pressure in the surrounding and asked some critical questions about pressure before she started her lesson on pressure. It can also be observed from Teacher K's lesson where the students stayed focus and excited when he started the lesson with a demonstration on combustion of alkane. Coe et al. (2014) suggested that teachers should understand the ways their students assess the content and able to have the capacity to assess the reasoning behind the students' own techniques. The students' interest will be triggered before the lesson with familiar phenomenon related to the topic and they will be more curious to find out more about the topic. This will increase their motivation to learn (Koballa et al., 2000).

\subsubsection{Instructional Decision}

The science teachers should allow students to involve in the discussion by eliciting examples that should be discussed in the lesson. Teacher $\mathrm{K}$ asked his students to state some alkanes before he explained on the reaction of the alkane. This interaction of teachers and students has a positive outcome on student achievement (NCEE, 2013) and teachers are able to know how well their students can understand the science concepts. As per Coe et al. (2014), effective teaching could motivate, engage and provoke students to learn and achieve higher goals. Thus, the students are able to score well in the examinations if the teachers know their students well.

\subsubsection{Knowledge Source}

It is good to demonstrate example in the classroom, but it is better to allow the students to conduct hands-on experiments or projects themselves. Coe et al. (2014) stated that by giving sufficient time for practising is the element of high-quality instruction. The findings found that the students were excited when they were able to conduct the experiments by themselves and experience the whole process. Teacher $\mathrm{E}$ and Teacher $\mathrm{H}$ allowed their students to conduct the experiments by themselves after they have explained on the science concepts whereas Teacher $\mathrm{M}$ asked his students to conduct a small experiment after he demonstrated it. Effective learning sometimes requires individual to fundamentally rebuild thinking (Msimanga, 2014). The utilization of hands-on learning activities and evaluation which emphasises on thinking skills through projects are positively affecting students' test scores (Wenglinsky, 2002). It is proven by Katukula (2018) where the majority of Finnish science teachers used experimental teaching methods, hence Finland managed to score well in PISA.

\subsubsection{Students' Success}

An effective teacher should define them based on their individual improvements. The teacher must be capable in assessing the reasonings behind the students' own particular techniques and identify students' common misconceptions (Coe et al., 2014). As Teacher A and Teacher C stated that students have different expertise. Teacher L also stated that they have different learning paces. Thus, teachers can define them based on their attitudes in learning science and not on their examination results.

\subsubsection{Learning Mode}

A good instructional practice should encourage students to work in groups. The students are given the chance to discuss among themselves and share their ideas with their classmates. A group approach has motivational value whereas competition among students in science classroom may demotivate them to learn science. According to Méndez López, and Bautista Tun (2017), students are motivated to learn in a supportive classroom environment whereas peer evaluation demotivated them. Group approach also enables every student to contribute in attaining common goals (AAAS, 1990). Therefore, the teacher can assign a project just like Teacher F and also divide the students into groups to conduct the experiments just like Teacher $\mathrm{H}$ and Teacher M.

\subsubsection{Motivation}

The science teachers should give comments and feedbacks to the students. The science teachers should praise their students when they able to answer the questions correctly. As indicated by Msimanga (2017), effective learning happens when students have the opportunities to reflect on their learning. The science teachers should 
correct their mistakes as observed in Malaysian classrooms which conducted by Teacher G and Teacher $\mathrm{H}$ and also Germany classrooms which conducted by Teacher L, Teacher M and Teacher P. Teachers must give students some time to reflect on the feedback they received and to try again (AAAS, 1990). Katukula (2018) also found that it is important for a science teacher to discuss and give comment by connecting practical work to theory.

\subsubsection{Assessment}

The science teacher should use a balanced of both repetition and application questions in the examination. The process-based assessment in the examination is to test on the conceptual understanding. Understanding should be the main purpose of science teaching. Without conceptual understanding, it is detracting science as a process and students will be misled on what they have learned (AAAS, 1990). The teacher must be able to use different questions to achieve different objectives of the lessons (Ko \& Sammons, 2013). Teacher A stated that repetition questions and application questions were included in the examinations. Teacher $\mathrm{R}$ also said that the examination questions always contain the mixture of repetitions questions which test for factual recall and new questions which test for conceptual understanding. Hence, they should include some questions to test on students' factual recall.

\subsubsection{Content}

The science teachers also should allow the students to think. They should allocate more time for the students to think. Students need time for exploring, making observations, testing ideas and reconstructing ideas when learning science (AAAS, 1990). To instill the science concepts in students, the concepts should not just be presented to students by their teachers. It should be offered to them in different contexts (AAAS, 1990). As observed in Teacher N's lesson where he waited the answer from his students, guided them when they unable to get it and corrected them until they got the physics concepts.

\subsubsection{Instructional Design}

The science teachers should have a lesson plan so that the lesson can be conducted smoothly and able to presume worthy learning experiences for the students (Saleh \& Liew, 2018). According to Ko and Sammons (2013), teachers must utilise different teaching strategies in order to reach different students. The teachers must plan well on the strategies based on classes before entering the classroom just like all the Malaysian science teachers. All Malaysian science teachers had a lesson plan where the objectives of the lesson were stated down. Besides, the science teachers to design and structure the classroom activities well and have clear learning goals for each lesson (Ko \& Sammons, 2013).

\subsubsection{Problem Solving}

There are different types of students in a classroom: some students are well-prepared in group task while some are not; some might be better while some might not (Ates \& Eryilmaz, 2010). Thus, teachers should ask well-defined questions in weaker class and more challenging questions for well-performed class. Teacher $\mathrm{K}$ and Teacher M said that they asked simple questions for weaker classes. This is because the students would not able to solve if difficult questions were asked. However, Teacher M stated that he asked tougher questions for the better academic class. Teachers may gradually challenge the students to achieve more (Gray \& Macblains, 2015). Different teaching methods enable students to explore different phenomena in different ways and allow them to relate science concepts to everyday life hence this maximises their understanding in science (Katukula, 2018).

\section{Conclusion}

In conclusion, there are similarities and differences in science teachers' instructional practices in Malaysia and Germany. Both nations have the same source of knowledge, same view of defining their students' success, learning modes, motivation given by teachers and problem-solving skills whereas the interactivity of the classroom, instructional decisions made in the lesson, method of assessment, the content used in the lesson and the instructional design showed huge different. The findings make a contribute to the improvement of education not only in Malaysia but also in Germany. This study showed the differences of the science teachers' instructional practices in Malaysian and German secondary schools. The findings showed that the Malaysian science teachers' instructional practices are moving toward alternative instructional practices where they can improve themselves by exchanging the idea and practices from the findings found in German and vice versa.

Moreover, ten good instructional practices in teaching science which found in both countries where they can adapt it in their science lesson were suggested in this study. It provided recommendations on the most proficient method to build the interest of students towards learning science. Different ways are expected to inspire the 
students to learn science with the goal that science will be a fascinating subject for them to learn and not an exhausting conceptual subject.

In this study, the comparison of Malaysian and German secondary science education was rather general. This comparison would be stronger if fore, one avenue for future comparative research between Malaysian and German secondary science education could be to analyse the content in the curriculum and other education policy documents and combine with the analysis done in this study. The main advantage of doing this could be to further develop the education system, for example, curriculum reform, teacher education development and school development.

\section{Acknowledgments}

Firstly, we would like to thank Universiti Sains Malaysia and Deutscher Akademischer Austauschdienst who gave the financial supported in this study. We would also like to thank all the sixteen participants that involved in this study. This accomplishment would not have been possible without them. Thank you.

\section{References}

Ates, Ö., \& Eryilmaz, A. (2010). Strengths and weaknesses of problem-based learning in engineering education: Students' and tutors' perspectives. Buca Egitim Fakültesi Dergisi, 28, 40-58.

Björkmana, J., \& Tiemanna, R. (2013). Teaching patterns of scientific inquiry: A video study of chemistry lessons in Germany and Sweden. Science Education Review Letters Research Letters, 1-7.

Braun, V., \& Clarke, V. (2006). Using thematic analysis in psychology. Qualitative Research in Psychology, 3, 77-101. https://doi.org/10.1191/1478088706qp063oa

Coe, R., Aloisi, C., Higgins, S., \& Major, L. E. (2014). What makes great teaching? Review of the underpinning research.

da Luz, F. S. d. R. (2015). The relationship between teachers and students in the classroom: Communicative language teaching approach and cooperative learning strategy to improve learning. Master dissertation. Bridgewater State University, USA. Retrieved from http://vc.bridgew.edu/theses/22

Dancy, M., \& Henderson, C. (2007). Framework of articulating instructional practices and conceptions. Physical Review Physics Education Research, 3(1). https://doi.org/10.1103/PhysRevSTPER.3.010103

Drossel, K., Eickelmann, B., \& Gerick, J. (2017) Predictors of teachers' use of ICT in school: The relevance of school characteristics, teachers' attitudes and teacher collaboration. Education and Information Technologies, 22(2), 551-573. https://doi.org/10.1007/s10639-016-9476-y.

Elliott, L. D. (1996). The teaching styles of adult educators at the Buckeye leadership workshop as measured by the principles of adult learning scale. The Ohio State University.

Emanalia, I, (2017). Teacher-centered or student-centered learning approach to promote learning? Jornal Sosial Humaniora. https://doi.org/10.12962/j24433527.v10i2.2161

Forbes, C., Lange, K., Möller, K., Biggers, M., Laux, M., \& Zangori, L. (2014). Explanation-construction in fourth-grade classrooms in Germany and the USA: A cross-national comparative video study. International Journal of Science Education, 36(14), 2367-2390.

Fraenkel, J. R., Wallen, N. E., \& Hyun, H. H. (2012). How to design and evaluate research in education (8th ed.). New York: McGraw-Hill. https://doi.org/10.1080/09500693.2014.923950

Grasha, A. F. (1996). Teaching with Style. Pittsburgh: Alliance Publishers.

Gray, C., \& MacBlain, S. (2015). Learning theories in childhood. London: Sage.

Hakim, C. (2000). Research design: Successful designs for social and economic research (2nd ed.). London: Routledge.

Ismail, I., Azizan, S. N., \& Gunasegaran, T. (2016). Mobile learning in Malaysian universities: Are students ready? International Journal of Interactive Mobile Technologies, 10(3). https://doi.org/10.3991/ijim.v10i3.5316

Katukula, K. M. (2018). Teaching methods in science education in Finland and Namibia. Master dissertation. University of Eastern Finland, Finland.

Kawulich, B. (2012). Collecting data through observation. In C. Wagner, B. Kawulich \& M. Garner (Eds.), Doing Social Research: A global context. Retrieved from 
https://www.researchgate.net/publication/257944783_Collecting_data_through_observation

Ko, J., \& Sammons, P. (2013). Effective teaching: a review of research and evidence. CfBT Education Trust.

Koballa, T., Graber, W., Coleman, D. C., \& Kemp, A. C. (2000). Prospective gymnasium teachers' conceptions of chemistry learning and teaching. International Journal of Science Education, 22(2), 209-224. https://doi.org/ 10.1080/095006900289967

Kurtz, B. E., Schneider, W., Carr, M., Borkowski, J. G., \& Rellinger, E. (1990). Strategy instruction and attributional beliefs in west Germany and the United States: Do teachers foster metacognitive development? Contemporary Educational Physhology, 15, 268-283. https://doi.org/10.1016/0361-476X(90)90024-U

Méndez López, M. G., \& Bautista Tun, M. (2017). Motivating and demotivating factors for students with low emotional intelligence to participate in speaking activities. Teachers' Professional Development, 19(2), 151-163. https://doi.org/10.15446/profile.v19n2.60652

Ministry of Education. (2015). Executive Summary Malaysia Education Blueprint 2013-2025 (Preschool to Post-Secondary Education). Retrieved from http://www.moe.gov.my/cms/upload_files/articlefile/2013/articlefile_file_003114.pdf

Msimanga, M. R. (2014). Managing teaching and learning in multi-graded classrooms in Thabo Mofutsanyana Education District, Free State. Master dissertation. Pretoria: University of South.

Msimanga, M. R. (2017). Teach and assess: A strategy for effective teaching and learning in economic and management sciences. Doctorate dissertation. University of The Free State Bloemfontein.

Mullis, I. V. S., Martin, M. O., Minnich, C. A., Stanco, G. M., Arora, A., Centurino, V. A. S., \& Castle, C. E. (2012a). TIMSS 2011 encyclopedia (volume 1: A-K). U.S.: TIMSS \& PIRLS International Study Center.

Mullis, I. V. S., Martin, M. O., Minnich, C. A., Stanco, G. M., Arora, A., Centurino, V. A. S., \& Castle, C. E. (2012b). TIMSS 2011 encyclopedia (volume 2: L-Z and benchmarking participants). U.S.: TIMSS \& PIRLS International Study Center.

NCEE Evaluation Brief. (2013). Instructional practices and student math achievement: Correlations from a study of math curricula.

OECD. (2012a). PISA 2012 Results in focus: What 15-year-olds know and what they can do with what they know. Retrieved from https://www.oecd.org/pisa/keyfindings/pisa-2012-results-overview.pdf

OECD. (2012b). PISA 2012 Results: Ready to learn. Students' engagement, drive and self-beliefs. Retrieved from http://www.oecd.org/pisa/keyfindings/pisa-2012-results-volume-III.pdf

OECD. (2009). Creating Effective Teaching and Learning Environments: First Results from TALIS. Paris: OECD Publishing. https://doi.org/10.1787/9789264068780-en

OECD. (2016). Programme for international student assessment (PISA) results from PISA 2015: Germany. Retrieved from http://www.oecd.org/pisa/pisa-2015-Germany.pdf

Papadakis, S. (2016). Creativity and innovation in European education. 10 years eTwinning. Past, present and the future. International Journal of Technology Enhanced Learning, 8(3), 279-296. https://doi.org/10.1504/IJTEL.2016.082315

Papadakis, S. (2018). Evaluating pre-service teachers' acceptance of mobile devices with regards to their age and gender: a case study in Greece. International Journal of Mobile Learning and Organisation, 12(4), 336-352. https://doi.org/10.1504/IJMLO.2018.095130

Papadakis, S., Kalogiannakis, M., \& Zaranis, N. (2016). Comparing tablets and PCs in teaching Mathematics: An attempt to improve mathematics competence in early childhood education. Preschool and Primary Education, 4(2), 241-253. https://doi.org/10.12681/ppej.8779

Parahoo, K. (1997). Nursing research: Principles, process and issues. Basingstoke: Macmillan. https://doi.org/10.1007/978-1-349-14559-1

Saleh, S., \& Aziz, A. (2012). Teaching Practices Among Secondary School Teachers in Malaysia. Paper presented at 2012 2nd International Conference on Education, Research and Innovation - ICERI 2012. Conference 28th to 29th September 2012. Phnom Penh, Cambodia.

Saleh, S., \& Liew, S. S. (2018). Classroom pedagogy in German and Malaysian secondary school: A comparative study. Asia Pacific Journal of Educators and Education, 33, 57-73. https://doi.org/10.21315/apjee2018.33.5 
Saleh, S., \& Yakob, N. (2014). Teachers' conceptions about physics instruction: A case study in Malaysian Sshools. Australian Journal of Basic and Applied Sciences, 8(24), 340-347.

Sim, W. S. L., \& Arshad, M. Y. (2013). A Typology of Teaching Styles among Chemistry Secondary School Teachers. International Journal of English and Education, 2(4).

Stevenson, H. W., \& Nerison-Low, R. (2002). To Sum It Up: Case Studies of Education in Germany, Japan, and the United States. National Institute on Student Achievement, Curriculum, and Assessment Office of Educational Research and Improvement U.S. Department of Education.

Tengku Kasim, T. S. A. (2014). Teaching paradigms: An analysis of traditional and student-centred approaches. Journal of Usuluddin, 40, 199-218.

Tengku Zainal, T. Z., Mustapha, R., \& Habib, A. R. (2009). Pengetahuan Pedagogi Isi Kandungan Guru Matematik bagi Tajuk Pecahan: Kajian Kes di Sekolah Rendah. Jurnal Pendidikan Malaysia, 34(1), 131153.

The Star. (2017). Success in life not defined by exam results. Retrieved from https://www.thestar.com.my/news/education/2017/04/09/success-in-life-not-defined-by-exam-results/

Tytler, R., Chen, H. S., \& Freitag-Amtmann, I. (2017). Inquiry teaching and learning within and across cultures. Paper presented at ESERA 2017 Conference Dublin City University, Dublin, Ireland, 21-29 August 2017.

Wenglinsky, H. (2002). How schools matter: The link between teacher classroom practices and student academic performance. Education Policy Analysis Archives, 10(12), 15. https://doi.org/10.14507/epaa.v10n12.2002

Zamir, Z. F., \& Faizli, A. A. (2013). TIMSS 2011: An analysis of Malaysia's achievement. Retrieved from http://aafaizli.com/timss-2011-an-analysis-of-malaysias-achievement/

\section{Copyrights}

Copyright for this article is retained by the author, with first publication rights granted to the journal.

This is an open-access article distributed under the terms and conditions of the Creative Commons Attribution license (http://creativecommons.org/licenses/by/4.0/). 